\title{
Application of Health Belief Model on Breast Self-Examination: A Meta-Analysis
}

\author{
Maranata'), Eti Poncorini Pamungkasari'), Rita Benya Adriani²) \\ 1)Masters Program of Public Health, Universitas Sebelas Maret \\ 2) Department of Nursing Polytechnic Health Surakarta Institution, Surakarta
}

\section{ABSTRACT}

Background: Breast cancer is a type of cancer and the leading cause of cancer death in women. BSE is an early detection method for breast cancer. Health Belief Model is a model of health behavior that can predict women's interest in practicing BSE. This study aims to estimate the Health Belief Model's effect in the practice of BSE by meta-analysis.

Subjects and Method: Meta-analysis was performed by searching for articles from the PubMed database, Springer Link, Elsevier, and Google Scholar. The keywords used were "health belief model," OR "health belief" OR "belief" AND "breast self-examination," OR "breast cancer screening." This study's inclusion criteria were full-text articles published in 2011-2020, a crosssectional study design. Article analysis using RevMan 5.3 software.
Results: There were 12 articles in total. The results showed that perceived benefits were strong $(\mathrm{aOR}=1.02 ; 95 \% \mathrm{CI}=0.94-1.11 ; \mathrm{p}=0.590$; $\left.\mathrm{I}^{2}=73 \%\right)$, perceived barriers were weak $(\mathrm{aOR}=1$; 95\% CI= 0.95-1.05; $\mathrm{p}=0.920 ; \mathrm{I}^{2}=87 \%$ ).

Conclusion: Perceived benefits and perceived barriers are not statistically significant in predicting BSE practice in women.

Keywords: health belief model, perceived benefits, perceived barriers, BSE

\section{Correspondence:}

Maranata. Masters Program in Public Health, Universitas Sebelas Maret. Jl. Ir. Sutami 36A, Surakarta 57126, Central Java. Email: maranataima@gmail.com. Mobile: 085867548771

Cite this as:

Maranata, Pamungkasari EP, Adriani RB (2020). Application of Health Belief Model on Breast Self-Examination: A Meta-Analysis. J Health Promote Behav. 05(03): 221-231. https://doi.org/10.26911/thejhpb.2020.05.03.08. cC (i) (-) Journal of Health Promotion and Behavior is licensed under a Creative Commons EY NC SA Attribution-Non Commercial-Share Alike 4.0 International License.

\section{BACKGROUND}

Breast cancer is a malignancy in the breast that originates from glandular cells, glandular ducts, and breast supporting tissue but not breast skin. Cancer cells can arise when a genetic mutation has occurred due to DNA damage in normal cells. Breast cancer causes lumps in the breast and menstrual pain (Dewi and Hendrati, 2015; Umami et al., 2020).

According to WHO (2020), breast cancer is the most common cancer and the most significant cause of death in women. Breast cancer sufferers in the world 2.1 million each year. In 2018, breast cancer's death rate was $15 \%$ of all death causes due to cancer in women. Global Cancer Observatory (GLOBO$\mathrm{CAN}$ ) data in 2018 in Indonesia reported that breast cancer incidence is 42.1 per 100,000 , with an average death rate of 17 per 100,000 (WHO, 2019).

The exact cause of breast cancer is not yet known, presumably many factors such as age, reproduction, genetics, lifestyle and hormones. The factor of increasing age is closely related to the incidence of breast cancer. Reproductive risk factors such as age at menarche, age at first gestation and age at menopause. Genetic risk factors are women whose mothers or sisters have breast cancer are more prone to breast cancer. Lifestyle risk factors such as alcohol consumption, excess 
fat consumption, less fiber consumption. Hormonal factors, namely high estrogen levels in the body (Listyawardhani et al., 2018; Sun et al., 2017).

Breast cancer screening has been shown to reduce mortality. Early breast cancer screening benefits women to undergo treatment earlier than when cancer is diagnosed at a late stage. Breast cancer screening includes a physical examination of the breast and mammography. Physical examination of the breast consists of breast self-examination (BSE) and clinical breast examination (CBE) (Fuller et al., 2016).

BSE is a breast cancer detection method used when mammography is not available in rural or urban areas far from health facilities. Women who do BSE every month can detect lumps at an early stage. BSE checks for normal breast shape and looks for changes in breast size or shape, lumps, skin, fluid and abnormal pain. BSE is the only method that detects abnormalities at an early stage. The advantages of using the BSE method are economical, easy to do, can be done independently and does not require special equipment (Fajriah et al., 2019).

The Health Belief Model theory is a health theory that can predict health behavior developed by Strecher and Rosenstock (Nugrahani et al., 2017). A study conducted by Fajriah et al. (2019) in Surakarta, Indonesia, stated that negative perceived barriers and strong self-efficacy could increase women's likelihood of doing BSE. In another study in Bali, Indonesia, perceived benefits, perceived barriers, and self-efficacy determine women doing BSE (Febriyanti et al., 2018).

This study aims to estimate the effect of the Health Belief Model, especially the constructs of perceived benefits and perceived barriers in BSE practice by meta-analysis.
SUBJECTS AND METHOD

\section{Study Design}

This was a meta-analysis study. This study's articles were obtained from the electronic database PubMed, Springer Link, Elsevier and Google Scholar. The keywords used were "health belief model," OR "health belief" OR "belief" AND "breast self-examination," OR "breast cancer screening."

\section{Inclusion Criteria}

The inclusion criteria used in this study were full-text articles with a cross-sectional design. Those articles were published in English from 2011 to 2020. The analysis of perceived benefits and perceived barriers until the study's final results were reported using the adjusted odds ratio (aOR).

\section{Exclusion Criteria}

In this study, the exclusion criteria were articles that had been meta-analysis, duplicated articles, and a sample of $<100$ participants.

\section{Operational Definition of Variables} BSE Practice. The practice of doing breast self-exams performed by women who were already menstruating using hands and mirrors.

Perceived benefits. The belief of a woman that doing BSE was an effort to detect breast cancer early, which is beneficial.

Perceived barriers. A woman's belief that to do BSE, there were obstacles such as not experiencing or difficulty in menstruation and not knowing the correct steps about it.

\section{Data Analysis}

The collected articles were processed using the Review Manager application (RevMan 5.3). Data processing was done by calculating the effect size and heterogeneity's value to determine the model for combining the research and forming the final meta-analysis results in the form of a forest plot and a funnel plot. 


\section{RESULTS}

The process of searching for articles used in this study from various electronic journal databases can be seen in Figure 1.

Figure 2 illustrates where the primary study was conducted. In total, 12 primary studies were originating from 2 continents, namely Asia and Africa. The primary studies were ten from Asia, namely five from Turkey, one from Yemen, one from Saudi Arabia, one from Iran, one from Iraq, and one from Indonesia. Two primary studies were coming from Africa and both from Ethiopia.

\section{Perceived Benefits}

A total of 10 articles were designed with a cross-sectional study that analyzed the application of perceived benefits in BSE practice.

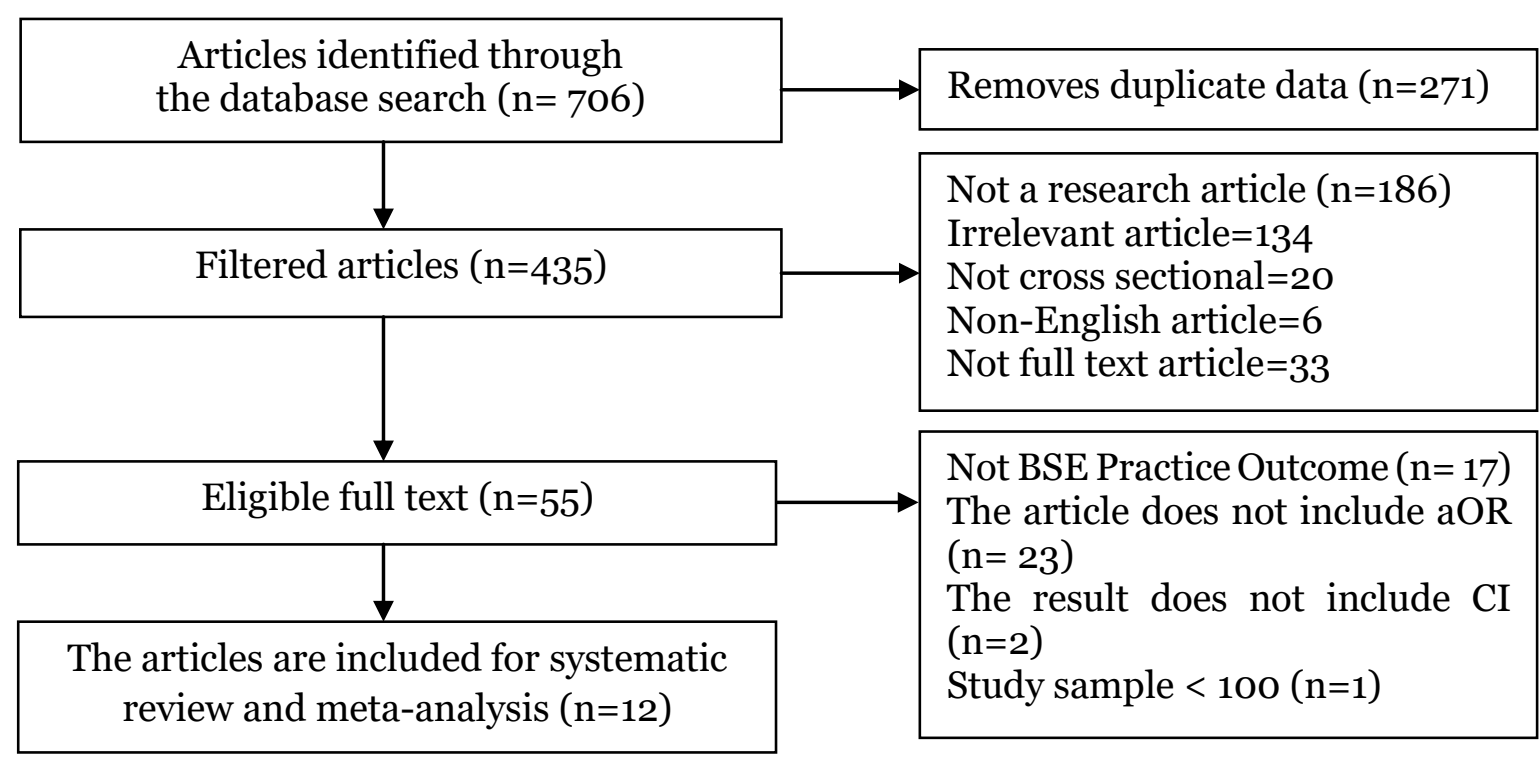

Figure 1. PRISMA flow diagram

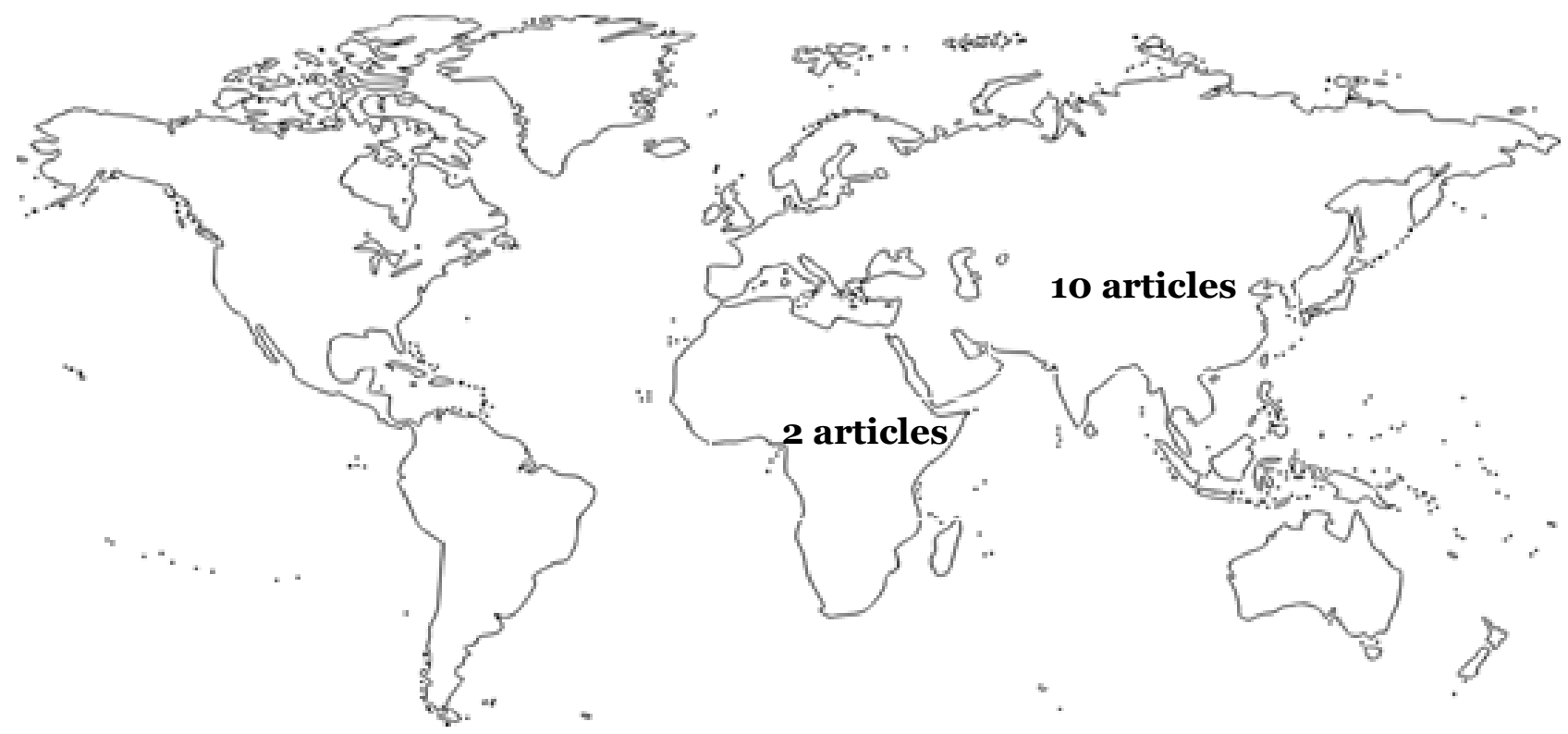

Figure 2. Map of the research area 
Table 1. Summary of the application source of perceived benefits in BSE practices

\begin{tabular}{|c|c|c|c|c|c|}
\hline $\begin{array}{l}\text { Author } \\
\text { (year) }\end{array}$ & Title & Location & Sample & $\begin{array}{l}\text { Intervention (I) and } \\
\text { Comparator (C) }\end{array}$ & Outcome \\
\hline $\begin{array}{l}\text { Selcuk et } \\
\text { al. (2020) }\end{array}$ & $\begin{array}{l}\text { Breast cancer screening } \\
\text { behaviors in women } \\
\text { aged } 40 \text { years and over } \\
\text { in a semi-urban region } \\
\text { in Turkey: relationships } \\
\text { with health beliefs }\end{array}$ & Turkey & 416 & $\begin{array}{l}\text { I: more perceived } \\
\text { benefits } \\
\text { C: fewer perceived } \\
\text { benefits }\end{array}$ & $\begin{array}{l}\text { Perceived } \\
\text { benefits } \\
\text { showed a } \\
\text { significant } \\
\text { correlation } \\
\text { with BSE }\end{array}$ \\
\hline $\begin{array}{l}\text { Basaran et } \\
\text { al. (2019) }\end{array}$ & $\begin{array}{l}\text { Health beliefs, behavior } \\
\text { and determining factors } \\
\text { in breast self-examina- } \\
\text { tion among university } \\
\text { students }\end{array}$ & Turkey & 877 & $\begin{array}{l}\text { I: good perceived } \\
\text { benefits } \\
\text { C: poor perceived } \\
\text { benefits }\end{array}$ & $\begin{array}{l}\text { Perceived } \\
\text { benefits did } \\
\text { not have a } \\
\text { significant } \\
\text { correlation } \\
\text { with BSE }\end{array}$ \\
\hline $\begin{array}{l}\text { Kirag dan } \\
\text { Klzllkaya. } \\
\text { (2019) }\end{array}$ & $\begin{array}{l}\text { Application of the cham- } \\
\text { pion health belief model } \\
\text { to determine beliefs and } \\
\text { behaviors of Turkish } \\
\text { woman academicians } \\
\text { regarding breast cancer } \\
\text { screening: a cross-sectio- } \\
\text { nal descriptive study }\end{array}$ & Turkey & 200 & $\begin{array}{l}\text { I: good perceived } \\
\text { benefits } \\
\text { C: poor perceived } \\
\text { benefits }\end{array}$ & $\begin{array}{l}\text { Perceived } \\
\text { benefits did } \\
\text { not have a } \\
\text { significant } \\
\text { correlation } \\
\text { with BSE }\end{array}$ \\
\hline $\begin{array}{l}\text { Nikpour et } \\
\text { al. (2019) }\end{array}$ & $\begin{array}{l}\text { Risk assessment for } \\
\text { breast cancer develop- } \\
\text { ment and its clinical } \\
\text { impact on screening per- }\end{array}$ & Iran & 800 & $\begin{array}{l}\text { I: positive perceived } \\
\text { benefits } \\
\text { C: negative perceived } \\
\text { benefits }\end{array}$ & $\begin{array}{l}\text { Perceived } \\
\text { benefits were } \\
\text { not related to } \\
\text { monthly BSE. }\end{array}$ \\
\hline
\end{tabular}

Shakor et Determinants of breast

al. (2019) self-examination prac-

tice among Iraqi/

Sulaiman women using

champion health belief

model and breast CAM

Dagnaw. $\quad$ Breast self - examina-

(2019) tion practice and its

associated factors

among undergraduate

female student at Uni-

versity of Gondar,

Northwest Ethiopia

$\begin{array}{lll}\text { Iraq } & 750 & \text { I: high perceived } \\ & \text { benefits } \\ & \text { C: low perceived } \\ & \text { benefits }\end{array}$

Iraq $\quad 803 \quad$ I: agreeable perceived

benefits

C: disagreeable

perceived benefits

\author{
Significant \\ perceived \\ benefits were \\ associated \\ with BSE \\ regularly. \\ Perceived \\ benefits were \\ not related to \\ BSE
}

Dewi et al. Determinants of breast

(2019) self - examination prac-

tice among women in

Surabaya, Indonesia: an

application of the health

$\begin{array}{lll}\text { Indonesia } & 1,967 & \text { I: high perceived } \\ & & \text { benefits } \\ & \text { C: low perceived } \\ & \text { benefits }\end{array}$

Yamen 400

$\begin{array}{ll}\text { Al-Sakkaf } & \text { Breast cancer know- } \\ \text { dan } & \text { ledge, perception, and } \\ \text { Basaleem. } & \text { breast self - examina- }\end{array}$

$\begin{array}{ll}\text { Al-Sakkaf } & \text { Breast cancer know- } \\ \text { dan } & \text { ledge, perception, and } \\ \text { Basaleem. } & \text { breast self - examina- }\end{array}$

(2016)
I: more perceived benefits

C: few perceived benefits tion practice among

Yemeni women: an

application of the health
Perceived benefits were significantly associated with BSE.
Significant predictors perceived benefits of BSE 
Maranata et al./ Application of Health Belief Model on Breast Self-Examination

\begin{tabular}{|c|c|c|c|c|c|}
\hline \multirow[b]{2}{*}{$\begin{array}{l}\text { Abolfotouh } \\
\text { et al. } \\
\text { (2015) }\end{array}$} & \multicolumn{5}{|l|}{ belief model } \\
\hline & $\begin{array}{l}\text { Using the health belief } \\
\text { model to predict breast } \\
\text { self-examination among } \\
\text { Saudi women }\end{array}$ & $\begin{array}{c}\text { Saudi } \\
\text { Arabia }\end{array}$ & 433 & $\begin{array}{l}\text { I: high perceived } \\
\text { benefits } \\
\text { C: low perceived } \\
\text { benefits }\end{array}$ & $\begin{array}{l}\text { High signifi- } \\
\text { cant percei- } \\
\text { ved benefits } \\
\text { had high BSE }\end{array}$ \\
\hline $\begin{array}{l}\text { Aker et al. } \\
(2015)\end{array}$ & $\begin{array}{l}\text { The practice of breast } \\
\text { cancer early diagnosis } \\
\text { methods among women } \\
\text { living in Samsun and } \\
\text { factors associated with } \\
\text { this practice }\end{array}$ & Turkey & 711 & $\begin{array}{l}\text { I: good perceived } \\
\text { benefits } \\
\text { C: poor perceived } \\
\text { benefits }\end{array}$ & $\begin{array}{l}\text { Perceived } \\
\text { benefits did } \\
\text { not affect } \\
\text { BSE }\end{array}$ \\
\hline
\end{tabular}

Based on table 1, it can be seen that there were ten articles with a total sample of 7,367

participants. Five studies stated that perceived benefits affected BSE.

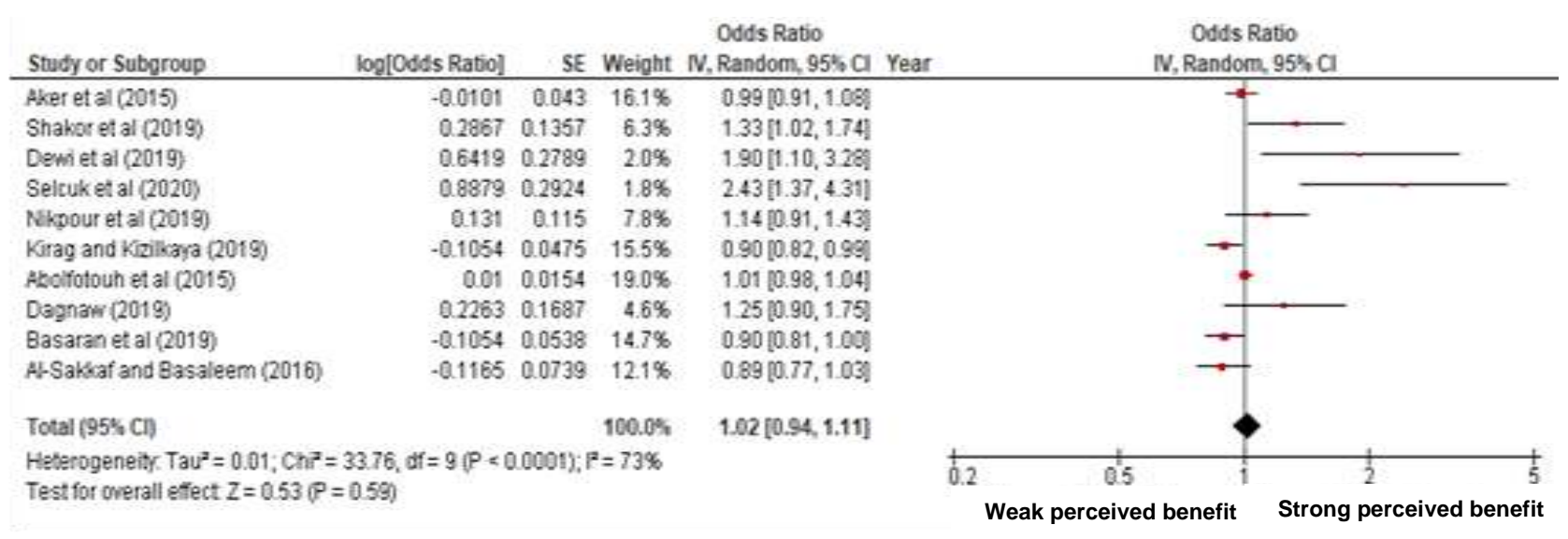

\section{Figure 3. Forest plot of the application of perceived benefits in BSE practices}

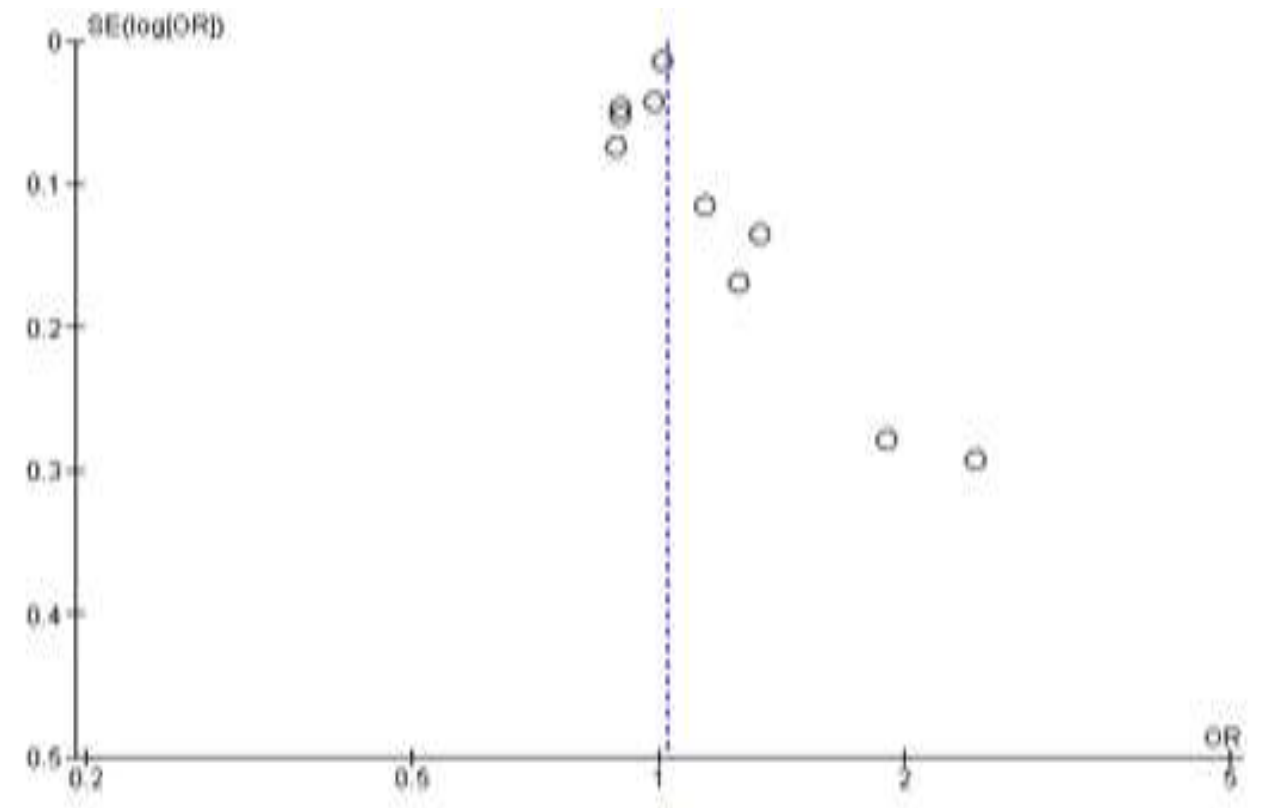

Figure 4. Funnel plot of the application of perceived benefits in BSE practices 
Based on Figure 3, it can be seen that there was high heterogeneity $\left(\mathrm{I}^{2}=73 \%\right.$; $\mathrm{p}$ $<0.001$ ), so data analysis in the forest plot used a random effect model. Strong perceived benefits increased the likelihood of BSE practice by 1.02 times compared to weak perceived benefits, and it was not statistically significant $(\mathrm{aOR}=1.02 ; 95 \% \mathrm{CI}=0.94-1.11$; $\mathrm{p}=0.590$ ). Based on Figure 4 , it can be concluded that there was a publication which was characterized by an asymmetry of the right and left plots where 5 plots are on the

Table 2. Summary of application sources

\begin{tabular}{|c|c|c|c|c|c|}
\hline $\begin{array}{c}\text { Author } \\
\text { (year) }\end{array}$ & Title & $\begin{array}{c}\text { Locat } \\
\text { ion }\end{array}$ & Sample & $\begin{array}{c}\text { Intervention (I) and } \\
\text { Comparator (C) }\end{array}$ & Outcome \\
\hline $\begin{array}{l}\text { Mekuria et } \\
\text { al. (2020) }\end{array}$ & $\begin{array}{l}\text { Breast self-examination practice } \\
\text { and associated factors among } \\
\text { secondary school female teachers } \\
\text { in Gammo Gofa Zone, Southern, } \\
\text { Ethiopia }\end{array}$ & $\begin{array}{l}\text { Ethio- } \\
\text { pia }\end{array}$ & 247 & $\begin{array}{l}\text { I: low perceived barriers } \\
\text { C: high perceived } \\
\text { barriers }\end{array}$ & $\begin{array}{l}\text { Low perceived } \\
\text { barriers had a } \\
\text { significant } \\
\text { correlation with } \\
\text { BSE }\end{array}$ \\
\hline $\begin{array}{l}\text { Basaran et } \\
\text { al. (2019) }\end{array}$ & $\begin{array}{l}\text { Health beliefs, behavior and } \\
\text { determining factors in breast self- } \\
\text { examination among university } \\
\text { students }\end{array}$ & Turkey & 877 & $\begin{array}{l}\text { I: poor perceived } \\
\text { barriers } \\
\text { C: good perceived } \\
\text { barriers }\end{array}$ & $\begin{array}{l}\text { Perceived } \\
\text { barriers were } \\
\text { not significant } \\
\text { toward BSE }\end{array}$ \\
\hline $\begin{array}{l}\text { Kirag dan } \\
\text { Klzllkaya. } \\
\text { (2019) }\end{array}$ & $\begin{array}{l}\text { Application of the champion } \\
\text { health belief model to determine } \\
\text { beliefs and behaviors of Turkish } \\
\text { woman academicians regarding } \\
\text { breast cancer screening: a cross- } \\
\text { sectional descriptive study }\end{array}$ & Turkey & 200 & $\begin{array}{l}\text { I: poor perceived } \\
\text { barriers } \\
\text { C: good perceived } \\
\text { barriers }\end{array}$ & $\begin{array}{l}\text { Women who did } \\
\text { BSE checks had } \\
\text { poor perceived } \\
\text { barriers. }\end{array}$ \\
\hline $\begin{array}{l}\text { Dewi et al. } \\
\text { (2019) }\end{array}$ & $\begin{array}{l}\text { Determinants of breast self - } \\
\text { examination practice among } \\
\text { women in Surabaya, Indonesia: } \\
\text { an application of the health belief } \\
\text { model }\end{array}$ & $\begin{array}{l}\text { Indone } \\
\text { sia }\end{array}$ & 1,967 & $\begin{array}{l}\text { I: low perceived barriers } \\
\text { C: high perceived } \\
\text { barriers }\end{array}$ & $\begin{array}{l}\text { Low perceived } \\
\text { barriers were } \\
\text { significantly } \\
\text { negatively } \\
\text { associated } \\
\text { with BSE }\end{array}$ \\
\hline $\begin{array}{l}\text { Abolfotouh } \\
\text { et al. (2015) }\end{array}$ & $\begin{array}{l}\text { Using the health belief model to } \\
\text { predict breast self-examination } \\
\text { among Saudi women }\end{array}$ & $\begin{array}{l}\text { Saudi } \\
\text { Arabia }\end{array}$ & 433 & $\begin{array}{l}\text { I: low perceived barriers } \\
\text { C: high perceived } \\
\text { barriers }\end{array}$ & $\begin{array}{l}\text { Significant } \\
\text { perceived } \\
\text { barriers } \\
\text { toward BSE }\end{array}$ \\
\hline $\begin{array}{l}\text { Aker et al. } \\
(2015)\end{array}$ & $\begin{array}{l}\text { The practice of breast cancer } \\
\text { early diagnosis methods among } \\
\text { women living in Samsun and } \\
\text { factors associated with this } \\
\text { practice }\end{array}$ & Turkey & 711 & $\begin{array}{l}\text { I: poor perceived } \\
\text { barriers } \\
\text { C: good perceived } \\
\text { barriers }\end{array}$ & $\begin{array}{l}\text { Perceived } \\
\text { barriers } \\
\text { affected BSE }\end{array}$ \\
\hline $\begin{array}{l}\text { Gursoy et al. } \\
\text { (2014) }\end{array}$ & $\begin{array}{l}\text { Attitudes and health beliefs } \\
\text { associated with breast cancer } \\
\text { screening behaviors among } \\
\text { Turkish women }\end{array}$ & Turkey & 399 & $\begin{array}{l}\text { I: low perceived barriers } \\
\text { C: high perceived } \\
\text { barriers }\end{array}$ & $\begin{array}{l}\text { Low perceived } \\
\text { barriers } \\
\text { affected BSE } \\
\text { practices }\end{array}$ \\
\hline
\end{tabular}

right, 4 plots are on the left, and 1 plot is at standard error 0 . The plot on the right was between the 0.1 and 0.3 standard errors. The plot on the left was between the 0 and 0.1 standard errors. Bias was also inferred from an imbalance in the distance between studies on both the right and left sides.

\section{Perceived Barriers}

A total of 7 articles with a cross-sectional design analyzed the application of perceived barriers in BSE practice. 
Maranata et al./ Application of Health Belief Model on Breast Self-Examination

Based on table 2, there were 7 articles with a the studies stated that there was an effect of total sample of 4,834 participants. Most of perceived barriers and the practice of BSE.

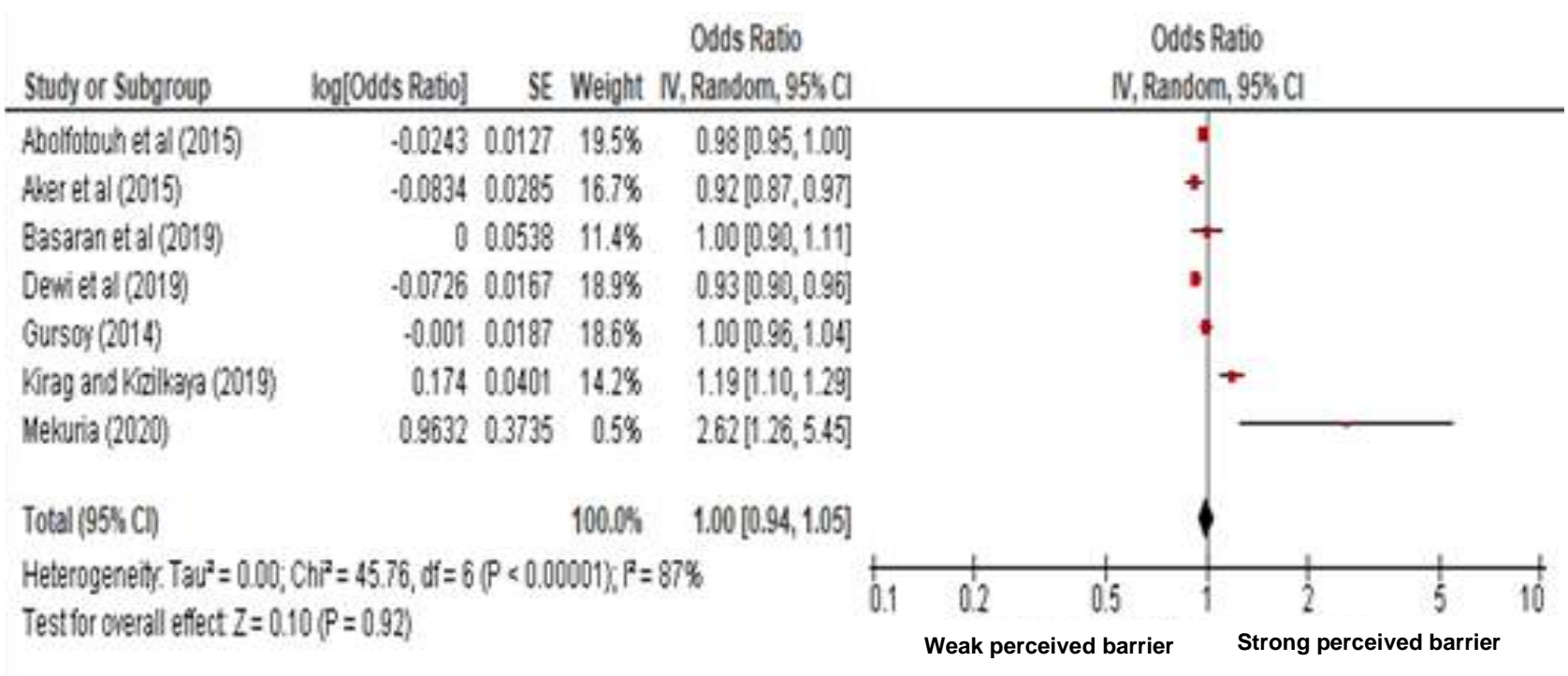

Figure 5. Forest plot of the application of perceived barriers in BSE practices

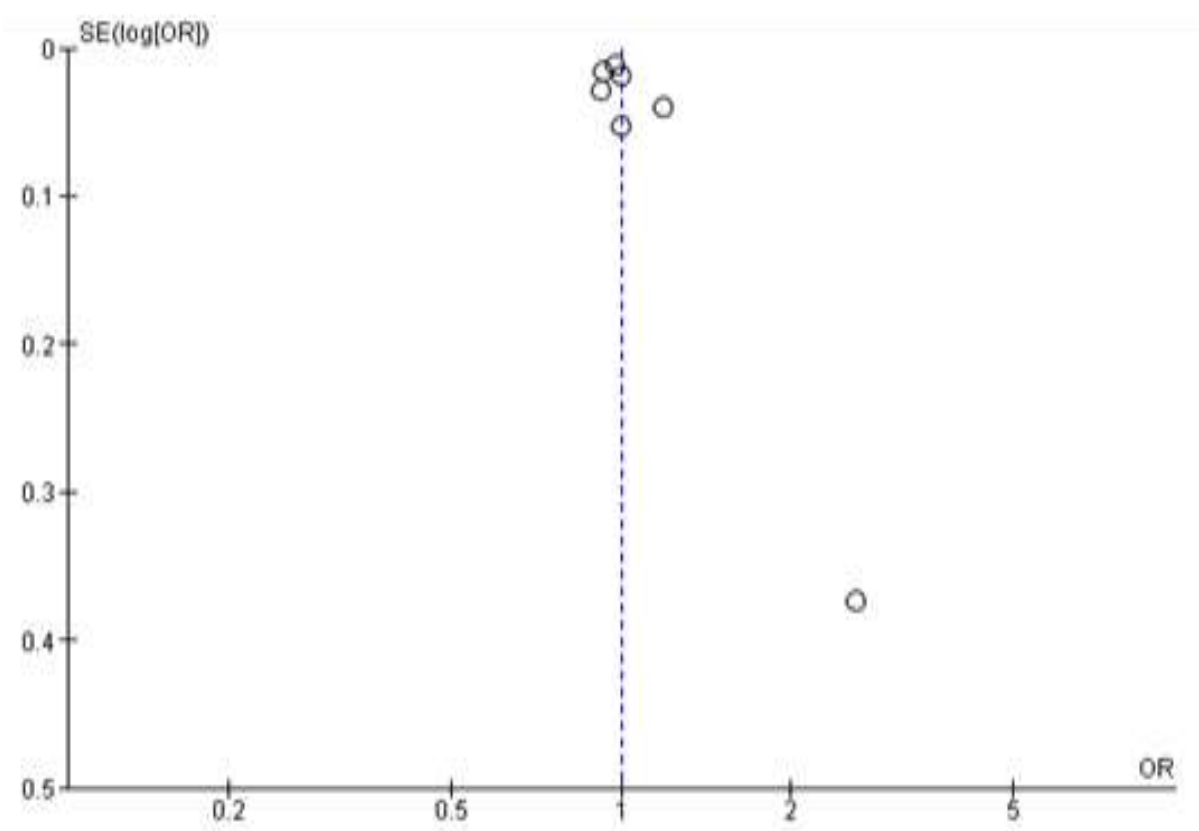

Figure 6. Funnel plot of the application of perceived ba rriers in BSE practices

Based on Figure 5, it can be seen that there was high heterogeneity (I2= 87\%; p $<0.001$ ), so data analysis in the forest plot used a random effect model. Weak perceived barriers had the same probability of doing BSE compared to strong perceived barriers and it was statistically insignificant $(\mathrm{aOR}=$ 1.00; 95\% CI=0.94-1.05; $\mathrm{p}=0.920$ ).

Based on Figure 6 it can be concluded that there was a publication bias characterized by the asymmetry of the right and left plots where 2 plots are on the right and 5 
plots were on the left. The plot on the right was between the 0 and 0.05 standard errors. The plot on the left was between the 0 and o.1 standard errors. Bias was also inferred from an imbalance in the distance between studies on both the right and left sides.

\section{DISCUSSION}

This systematic review and meta-analysis study take the theme of applying the health belief model in BSE practice. The independent variables of this study were perceived benefits and perceived barriers. The dependent variable of this study was the BSE practice.

This study uses the aOR statistical results from multivariate analysis, which aims to control confounding factors. Confounding factors can cause the study results to be invalid because confounding factors also influence the relationship or affect the population studied (Anulus et al., 2019).

\section{The application of perceived bene- fits in BSE practices}

This study indicated that strong perceived benefits had a slightly greater probability of doing BSE than weak perceived benefits, but it was not statistically significant. This study's results are in line with the study conducted by Tahmasebi and Noroozi (2016), which stated that perceived benefits could affect the practice of BSE, but it was not statistically significant. Ozkan et al. (2011) also stated that perceived benefit was not statistically significant in predicting BSE behavior.

Perceived benefits are the extent to which a person perceives behavior changes as beneficial and the extent to which they believe the behavior can prevent the risk of disease when a person makes changes to the required behavior. High perceived benefit is closely related to early diagnosis of disease and improved disease treatment, decreased cancer-related mortality, longer survival and improved quality of life (Selcuk et al., 2020).
Perceived benefits based on this study can increase the likelihood of doing BSE because the perceived benefit is one predictor of breast self-examination (Darvishpour et al., 2018).

Perceived benefits that can affect women to do BSE include the perceived benefits of doing BSE, reducing the risk of breast cancer, the benefits of which the BSE method is an easy and cost-free early detection method for breast cancer, reduce breast cancer deaths, early detection, and opportunities for recovery and maintaining health status are longer (Ergin et al., 2012).

\section{Application of perceived barriers in BSE practices}

The results of this study indicated that there was no significant effect of perceived barriers on BSE practice. Women with a weak perceived barrier had the same likelihood of doing BSE as women who had a strong perceived barrier. This study's results are in line with a study conducted by Tahmasebi and Noroozi (2016), which stated that perceived barriers did not significantly affect BSE. Veena et al. (2015) also stated that perceived barriers did not statistically affect BSE's practice.

Perceived barriers are perceptions of factors that hinder health behavior or factors that make health behavior difficult to do. Perceived barriers can be changed by carrying out education, counseling, and efforts to increase access to health services so that the perceived barriers are reduced (Selcuk et al., 2020).

One of the obstacles that are felt in carrying out the practice of BSE is probably from culture. Different cultural backgrounds or social stigma make women reluctant to accept breast cancer knowledge. There is a misconception that breast cancer occurs due to residence location (Fajriah et al., 2019). 


\section{AUTHOR CONTRIBUTION}

Maranata, as the main researcher, designed this study, collected articles from electronic journal databases and analyzed the data. Eti Poncorini provided direction in data interpretation. Rita Benya Adriani gave directions in the preparation of publications.

\section{CONFLICT OF INTEREST}

The researchers stated that there was no conflict of interest in this study.

\section{FUNDING AND SPONSORSHIP}

This study used the main research funds.

\section{ACKNOWLEDGEIMENT}

The authors would like to express their gratitude to the database providers PubMed, Springer Link, Elsevier, and Google Scholar.

\section{REFERENCE}

Abolfotouh MA, Banimustafa AA, Mahfouz AA, Al-Assiri MH, Al-Juhani AF, Alaskar AS (2015). Using the health belief model to predict breast self examination among Saudi women. BMC Public Health, 15(1163): 1-12. https://doi.org/10.1186/s12889-015-2510-y.

Aker S, Oz H, Kaynar TE (2015). Practice of Breast Cancer Early Diagnosis Methods among Women Living in Samsun, and Factors Associated with This Practice. J Breast Health, 11(3): 115-122. https://doi.org/10.5152/tjbh.2015.2547.

Al-Sakkaf KA, Basaleem HO (2016). Breast cancer knowledge, perception and breast self- examination practices among yemeni women: An application of the Health Belief Model. Asian Pac J Cancer Prev, 17(3): 1463-1467. https://doi.org/10.7314/APJCP.2016.17.3.1463.

Anulus A, Murti B, Prasetya H (2019). Risk Factors of HIV among Male Military Personnels: A Meta Analysis. J Health
Promot Behav, 4(3): 178-188. https://doi.org/10.26911/thejhpb.2019.04.03.03.

Basaran O, Uskun E, Erturk C, Savas P. (2019). Health beliefs, behaviour and determining factors in breast self examination among a group of university students. Marmara Med J, 32(3): 130-136. https://doi.org/10.5472/marumj.638115.

Dagnaw, M. (2019). Breast self-examination practice and its associated factors among undergraduate female students at University of Gondar, Northwest Ethiopia. JAIR, 8(3): 62-67.

Darvishpour A, Vajari SM, Noroozi S. (2018). Can health belief model predict breast cancer screening behaviors? Maced J Medi Sci, 6(5): 1857-9655. https://doi.org/10.3889/oamjms.2018.183

Dewi GAT, Hendrati LY. (2015). Analisi Risiko Kanker Payudara berdasarkan Riwayat Kontrasepsi Hormonal dan Menarche. J Berkala Epidemiologi, 3(1): 12-23. Retrieved from https://www.researchgate.net/publication/313947330_Breast_Cancer_Risk_Analysis_by_the_Use_of_Hormonal_Contraceptives_and_Age_of_Menarche/link/58bobb4a45851503be97f103/download.

Dewi TK, Massar K, Ruiter RAC, Leonardi T. (2019). Determinants of breast selfexamination practice among women in Surabaya, Indonesia: An application of the health belief model. BMC Public Health, 19(1581): 1-8. Retrieved From https://doi.org/10.1186/s12889-0197951-2.

Ergin AB, Sahin NH, Sahin FM, Yaban ZS, Acar Z, Bektas H. (2012). Meta analysis of studies about breast self examination between 2000-2009 in Turkey. Asian Pac J Cancer Prev, 13(7): 3389-3397. Retrieved from https://doi.org/10.7314/- 
Maranata et al./ Application of Health Belief Model on Breast Self-Examination

APJCP.2012.13.7.3389.

Fajriah AS, Respati SH, Murti B. (2019). Theory of Planned Behavior and Health Belief Model on Factors Associated with Breast Self Examination among University Students. J Health Promot Behav, 4(4): 246-257.

Febriyanti NMA, Lubis D, Wirawan DN, Suariyani NLP, Karmaya M. (2018). The determinants of early breast cancer detection via breast self-examination (BSE) in Denpasar, Bali. Public Health Prev Med, 6(1): 37.https://doi.org/10.15562/phpma.v6i1.7.

Fuller MS, Lee CI, Elmore JG. (2016). Breast Cancer Screening: An Evidence-Based Update. Med Clin North Am, 99(3): 451-468. Retrieved from https://doi.org/10.1016/j.mcna.2015.01.002.Breast

Kirag N, Kizilkaya M (2019). Application of the Champion Health Belief Model to determine beliefs and behaviors of Turkish women academicians regarding breast cancer screening: A cross sectional descriptive study. BMC Women's Health, 19(1): 1-10. Retrieved from https://doi.org/10.1186/s12905019-0828-9.

Listyawardhani Y, Mudigdo A, Adriani RB. (2018). Risk Factors of Breast Cancer in Women: A New Evidence from Surakarta, Central Java, Indonesia. J Epidemiol Public Health, 3(2), 118-127. Retrieved from https://doi.org/10.26911/mid.icph.2018.01.13.

Nikpour M, Hajian-Tilaki K, Bakhtiari A (2019). Risk assessment for breast cancer development and its clinical impact on screening performance in Iranian women. Cancer Manag and Research, 11: 10073-10082. Retrieved from https://doi.org/10.2147/CMAR.S229585.

Nugrahani RR, Budihastuti UR, Pamungkasari EP (2017). Health Belief Model on the Factors Associated With the Use of Hpv Vaccine for the Prevention of Cervical Cancer Among Women in Kediri, East Java. J Epidemiol Public Health 2(1): 70-81. Retrieved from https://doi.org/10.26911/theicph.2017.009.

Ozkan A, Malak AT, Gürkan A, Turgay A. S. (2011). Do Turkish nursing and midwifery students teach breast self-examination to their relatives? Asian Pac J Cancer Prev, 12(1): 111-115.

Selcuk KT, Avci D, Dundar GY, Merca Y. (2020). Breast Cancer Screening Behaviors in Women Aged 40 Years and Over in a Semi-Urban Region in Turkey: Relationships with Health Beliefs. Healthcare, 8(171): 1-10. https://doi.org/10.3390/healthcare8020171.

Shakor JK, Mohammed AK, Karotia D. (2019). Determinants of Breast SelfExamination Practice amongst Iraqi/ Sulaimani Women using Champion Health Belief Model and Breast CAM. Int J Med Res Health Sci, 8(9): 51-59.

Sun YS, Zhao Z, Yang ZN, Xu F, Lu HJ, Zhu ZY, Shi W, Jiang J, Yao PP, Zhu HP. (2017). Risk factors and preventions of breast cancer. Inter J Biol Sci, 13(11): 1387-1397. Retrieved from https://doi.org/10.7150/ijbs.21635.

Tahmasebi R, Noroozi A. (2016). Is health locus of control a modifying factor in the health belief model for prediction of breast self-examination? Asian Pac J Cancer Prev, 17(4): 2229-2233. https://doi.org/10.7314/APJCP.2016.17.4.2229.

Umami A, Wahyu T, Pratama Y. (2020). Knowledge, Barriers, and Motivation Related to Breast and Cervical Cancer Screening Among Women in Bojonegoro, East Java: A Qualitative Study. J Health Promot Behav, 5(1): 1-10.

Veena K, Kollipaka R, Rekha R. (2015). The 
Maranata et al./ Application of Health Belief Model on Breast Self-Examination

knowledge and attitude of breast self examination and mammography among rural women. Int $\mathrm{J}$ Reprod Contracept Obstet Gynecol, 4(5): 15111516. Retrieved from https://doi.org/10.18203/2320-1770.ijrcog20150738 WHO. (2019). Indonesia Source GLOBOCAN
2018. International Agency for Research on Cancer. http://gco.iarc.fr/ WHO. (2020). Breast cancer. Retrieved from https://www.who.int/cancer/prevention/diagnosis-screening/breast-cancer/en/. 